\section{Intensity modulated radiation therapy vs 3D conformal radiotherapy in the radical treatment prostate cancer-analysis of acute and late toxicity}

Slavica Maric ${ }^{1}$, Ljiljana Tadić Latinovic ${ }^{2}$, Branislava Jakovljevic ${ }^{3}$, Milan Zigic ${ }^{4}$, Pavle Banovic ${ }^{1}$, Aleksandar Kostovski ${ }^{1}$, Goran Kolarevic ${ }^{1}$

${ }^{1}$ International medical centers Banja Luka, Center for Radiotherapy, Banja Luka, Republic of Srpska

${ }^{2}$ University Clinical Center of Republika Srpska, Institute of Pathology, Banja Luka, Republic of Srpska

${ }^{3}$ S-Tetic Health Institution, Oncology Department, Banja Luka, Republic of Srpska

${ }^{4}$ University Clinical Center of the Republic of Srpska, Clinic for Urology, Banja Luka, Republic of Srpska

\section{Abstract}

Implementation of IMRT offers possibility to escalate radiation therapy dose without increased acute and late toxicity. The aim of this study is to compare acute and late genitourinary and gastrointestinal toxicity in patients treated with IMRT and 3DCRT technique. This study included 35 patients in study group A treated with IMRT technique, and 35 patients in study group B treated with 3DCRT technique. Patients were selected and referred to radical radiotherapy treatment prostate cancer. Acute genitourinary and gastrointestinal toxicity was evaluated during radiotherapy treatment according to recommendation of RTOG group. Late gastrointestinal and genitourinary toxicity was evaluated during regular control exams after radical radiotherapy treatment for six months. Based on the results $\chi 2$ test there was no statistical significant difference $(p>0,05)$ between study group A i B in terms of acute gastrointestinal and genitourinary despite escalated radiotherapy dose in study group B treated with IMRT technique. Based on the results $\chi 2$ test there was no statistical significant difference $(p>0,05)$ between study group A i B in terms of late gastrointestinal and genitourinary toxicity. Intensity modulated radiation therapy is optimal technique in the radical treatment prostate cancer. This technique allows clinical benefit compared with 3D conformal radiotherapy-escalation of radiotherapy dose without increased toxicity in patients treated with IMRT technique.

Key words: 3D conformal radiotherapy, Intensity modulated radiation therapy, acute toxicity.

\section{Intenzitetom modulisana zračna terapija vs 3D konformalna zračna terapija u radikalnom tretmanu karcinoma prostate - analizaakutnih i hroničnih neželjenih efekata}

Slavica Marić1, Ljiljana Tadić Latinović ${ }^{2}$ Branislava Jakovljević ${ }^{3}$, Milan Žigić ${ }^{4}$, Pavle Banović ${ }^{1}$, Aleksandar Kostovski ${ }^{1}$, Goran Kolarević ${ }^{1}$

${ }^{1}$ International medical Centers Banja Luka- Centar za Radioterapiju, Dvanaest beba bb Banja Luka, Republika Srpska

${ }^{2}$ Univerzitetski klinički centar Republike Srpske, Zavod za patologiju, Dvanaest beba bb Banja Luka, Republika Srpska

${ }^{3} \mathrm{~S}-$ Tetik zdravstvena ustanova, Odjeljenje za onkologiju, Banja Luka, Republika Srpska

${ }^{4}$ Univerzitetski klinički centar Republike Srpske, Klinika za urologiju, Banja Luka, Republika Srpska

\section{Apstrakt}

Implementacijom IMRT tehnike moguće je eskalirati radioterapijsku dozu bez povećane incidence akutnih i hroničnih neželjenih efekata. Cilj ove studije je kompariranje akutnih i hroničnih genitourinarnih i gastrointestinalnih neželjenih efekata, kod pacijenata planiranih 3D CRT i IMRT tehnikom. Ova studija je uključila 35 pacijenata u studijskoj grupi A planiranih IMRT tehnikom, i 35 pacijenata u studijskoj grupi B planiranih 3D CRT tehnikom. Pacijenti su selektirani i upućeni na radikalni zračni tretman karcinoma prostate. Akutni genitourinarni i gastrointestinalni toksicitet je evaluiran tokom radioterapijskog tretmana, prema preporukama RTOG grupe. Kasni gastrointestinalni i genitourinarni neželjeni efekti su evaluirani tokom redovnih kontrolnih pregleda 6 mjeseci nakon završenog zračnog tretmana. Bazirano na rezultatima $\chi 2$ testa nije bilo statistički signifikantne razlike $(\mathrm{p}>0,05)$ izmedju studijskih grupa A i B kada su u pitanju akutni gastrointestinalni i genitourinarni efekti, uprkos eskaliranoj radioterapijskoj dozi u studijskoj grupi B planiranoj IMRT tehnikom. Prema rezultatima $\chi 2$ testa nije bilostatistički signifikantne razlike $(p>0,05)$ izmedju studijske grupeA i B kada su u pitanju hronični gastrointestinalni i genitourinarni neželjeni efekti. Intenzitetom modulisana zračna terapija je optimalna radioterapijska tehnika u radikalnom tretmanu karcinoma prostate. Ova tehnika omogućava klinički benefit u poređenju sa 3D konformalnom radioterapijom eskalaciju radioterapijske doze bez povećanog toksiciteta kod pacijenata planiranih IMRT tehnikom.

Ključne reči: 3D konformalna radioterapija, Intenzitetom modulisana zračna terapija, neželjeni efekti 


\section{Intorduction}

Prostate cancer is the second most commonly diagnosed type of cancer in male population, immediately after lung cancer ( 899.000 new cancer cases, $13.6 \%$ in total). Incidence is very high in developed countriesover three quarters of cases ${ }^{1}$. By 2030, it is expected that the proportion of men older than 65 years will reach about $20 \%$ of population, and that age is at increased risk for diagnosis of prostate cancer ${ }^{2}$. According to National Comprehensive Cancer Network NCCN recommandations for treatment of prostate cancer, patients in any risk group can have indications for radiotherapy in primary setting as radical treatment, or as onemodalityof treatment ${ }^{3}$. Having in mind, that five year overall survival in the group of clinically localized prostate cancer is almost $100 \%$, it is very clear that radiotherapy plays an important role in radical treatment of prostate cancer ${ }^{4}$. 3D conformal radiotherapy was introduced in 1980 and was the first form radiotherapy that can conform shape of the beam to the shape of the tumor. The goal of conformal radiotherapy is to deliver high radiation dose to the tumor, while minimizing radiation therapy dose in organs of risk ${ }^{5}$.

Intensity Modulated Radiation Therapy is technological advancement in Conformal Radiotherapy and it is unique technique because it allows inverse planning. The essence of Intensity of Modulated Radiotherapy is the use of the intensity of modulated beams that allow two or more intensity levels for any direction of the beam and for any position of the source. Using this mechanism, plans developed by Intensity Modulated Radiotherapy are able to generate concave dose distribution and dose gradients with sharper margins than 3DCRT technique ${ }^{6}$. Several clinical studies show benefit of escalation of the dose in the radical treatment of clinically localized prostate carcinoma ${ }^{7,8}$. The Intensity Modulated Radiation therapy can provide clinical benefit in terms of increased tumor control due to the escalation of the dose, which is extremely important in the radical treatment of prostatic carcinoma. Theoretically, the escalated dose with IMRT technique can increase the incidence of acute and late gastrointestinal and genitourinary side effects. The implementation of the Intensity Modulated Radiation Therapy requires a significant investment both in equipment and in a radiation therapy workflow that is more demanding than Three-Dimensional Conformal Radiotherapy (planning process, quality control, patient positioning and daily verification of precision of the plan). Previous studies demonstrates in most cases that Intensity Modulated Radiation Therapy compared to ThreeDimensional Conformal Radiotherapy is superior in the radical treatment of clinically localized prostatic carcinoma, particularly in terms of reducing the acute and late gastrointestinal and genitourinary toxicity in the escalated radiation dose regime above $70 \mathrm{~Gy} 9$.

The aim of this study is to confirm that IMRT is an optimal technique in radical treatment prostate cancer, which allows the escalation of radiation therapy dose without escalation of acute and late genitourinary and gastrointestinal toxicity.

\section{Material and Methods}

The study was conducted over 70 patients with pathohistollogically verified, clinically localized prostate cancer in IMC Banja Luka in the period from September 2014 to January 2017. Inclusion parameters were: Adenoca prostate, low risk and intermediate risk group, Gleason score (GS) ${ }^{6,7}$, Prostate specific antigen PSA less than 10 or 10-20ng/ml, TNM classification T1-T2a, b, c N0 M0 (10). Patients were divided into two groups (group A and group B), in which radical treatment wereplanned with different radiotherapy techniques. In the first group $\mathrm{N}=35$ (group A), radical treatment was planned with Three-Dimensional Conformal Radiotherapy (3DCRT). In the second group $\mathrm{N}=35$ (group B), a radical treatment was planned with Intensity Modulated Radiotherapy (IMRT). In study group B planned with IMRT, the preparation also contains a consultative exam of urologist and the implantation of fiducial gold markers in prostate ${ }^{11}$. After an adequate preparation of the patient, the urologist implanted three fiducial gold markers in the prostate-two into the prostate base, one into the apex Figure 1. 


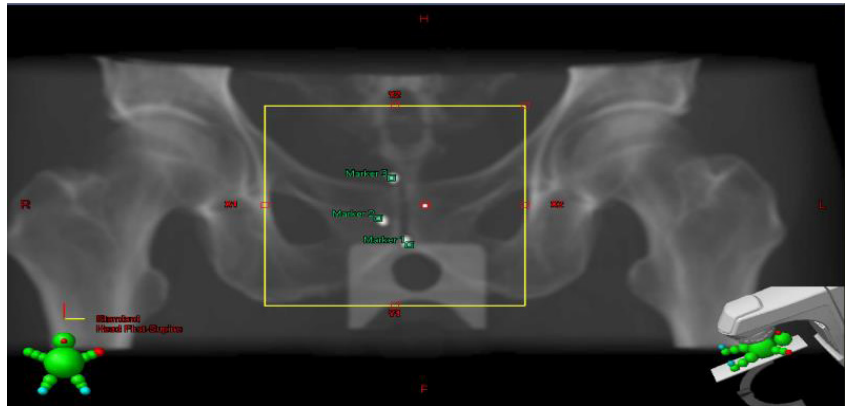

Figure 1. Implanted gold fiducial markers in prostate

Fiducial markers allows adequate verification of the prostate position before delivery of treatment, and reduce the possibility of inter and intra-fraction movement of the prostate ${ }^{12}$. Patients in study group A were planned on the Eclipse Planning System -Varian Medical Systems version 10.0 and treated with the ThreeDimensional Conformal Radiotherapy technique on Linear Accelerator Clinac DHX Varian Medical Systems Figure 2. and Figure 3.

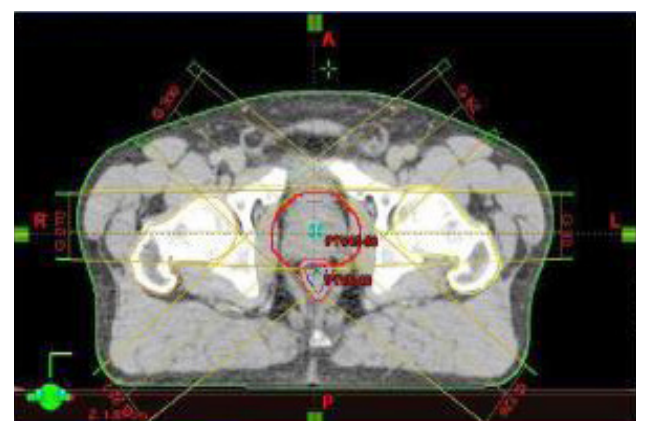

Figure 2. 3D Conformal plan prostate cancer

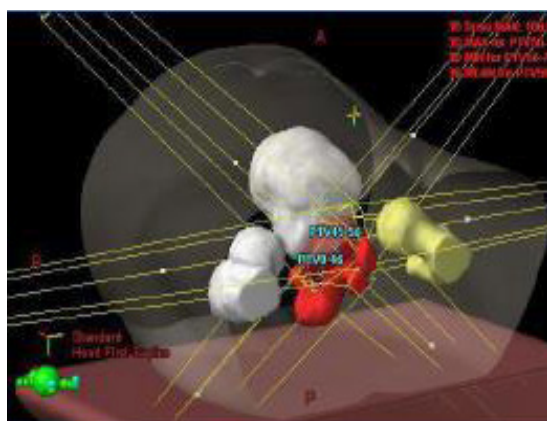

Figure 3. Radical 3DCRT technique

In 18 patients the prescribed dose was 70 Grey in 35 fractions, while in 17 patients the prescribed dose was 74Gy. Patients in study group B patient were planned by inverse planning on the Eclipse Planning System Varian Medical Systems, version 10.0 and treated with Intensity Modulated Radiation Therapy on Linear Accelerator Clinac DHX Varian Medical Systems. The prescribed dose was 78 Gy in 39 fractions in all patients Figure 4. and Figure 5.

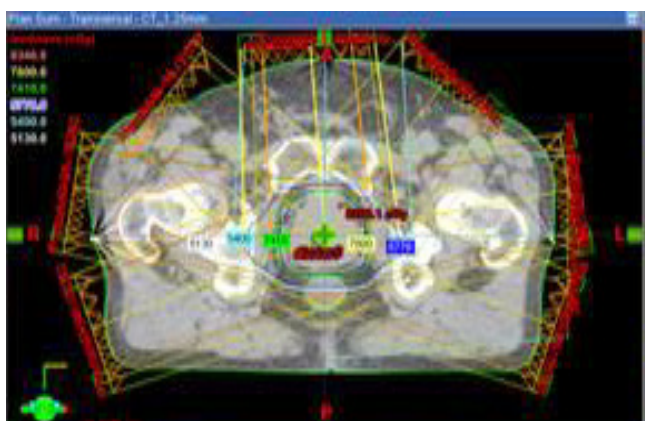

Figure 4. IMRT plan prostate cancer

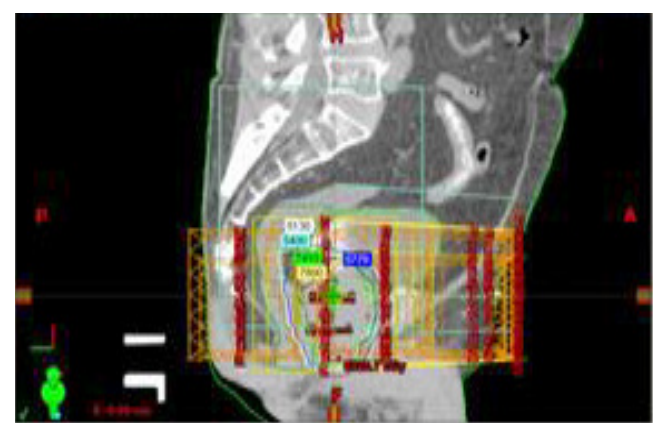

Figure 5. Radical IMRT treatment

Recommendations of the Radiation Therapy Oncology Group and the European Organization for Research and Treatment of Cancer (EORTC) were used in evaluation of acute and late genitourinary and gastrointestinal toxicity ${ }^{13}$. Acute gastrointestinal and genitourinary toxicity were evaluated on regular weekly control exams during radical radiotherapy treatment (Grade 0, Grade 1, Grade 2, Grade 3 and Grade 4). Late gastrointestinal and genitourinary toxicity effects were evaluated during regular control exams after radical radiotherapy 
treatment for six months (Grade 0, Grade 1, Grade 2, Grade 3 and Grade 4). The T-test was used to compare registered values. The statistical difference considered significant was $\mathrm{p}<0.05$.

\section{Results and discussion}

The results obtained from study group A and study group B correspond with the literature data which indicate that prostate cancer is a disease of older age male population. $69 \%$ patients in study group A were older than 70 year, $60 \%$ patients in study group B were older than 70 years Chart 1 and Chart 2.

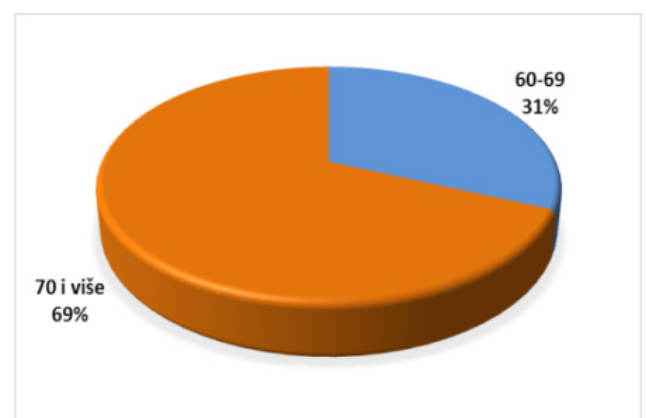

Chart 1. Study group A age range

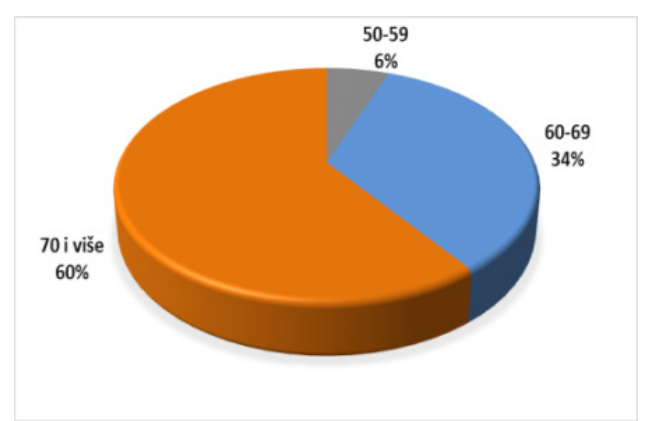

Chart 2. Study group B age range

In study Group B planned with IMRT technique, the number of patients with GS value 6 was dominant in relation to the number of patients who had GS value 7 Chart 3. and Chart 4 . These results were expected because the selection of the patient for the implantation of fiducial gold markers included patients with extremely low risk and favorable prognostic parameters

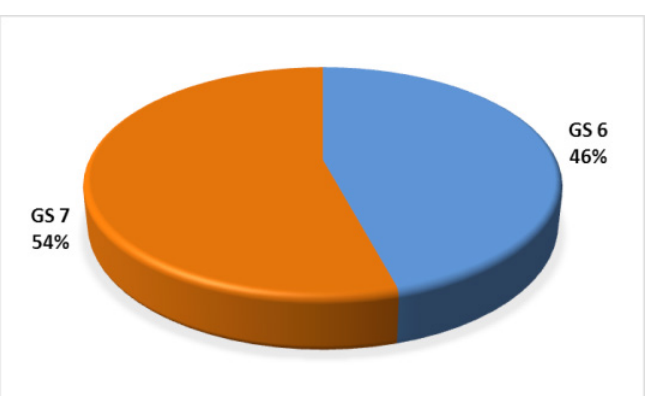

Chart 3. Gleason score distribution-Study group A

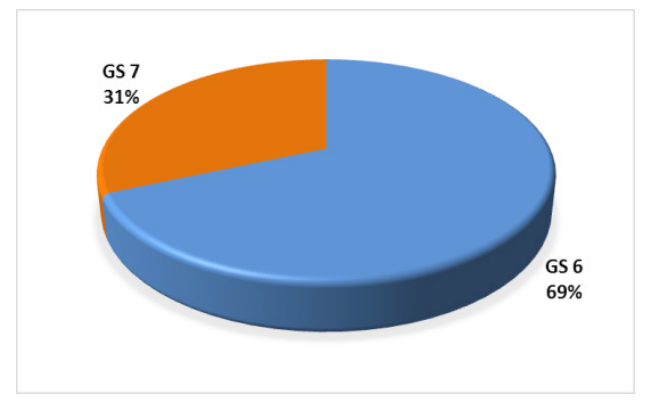

Chart 4. Gleason score distribution-Study group B

Distribution of patients study group A according to TNM classification and T status are shown in Table 1.

\begin{tabular}{|c|c|c|}
\hline T1a & 5 & 14,29 \\
\hline T2a & 10 & 28,57 \\
\hline T2b & 14 & 40,00 \\
\hline T2c & 6 & 17,14 \\
\hline Total & 35 & 100,00 \\
\hline
\end{tabular}

Table 1. T status study group A

Distribution of patients study group B according to TNM classification and T status are shown in Table 2. This study included patients with clinically localized prostate cancer, the clinical stage of the patients was T1a-T2c, and there was no statistically significant difference in TNM classification in study group A and study group B. 


\begin{tabular}{|c|c|c|}
\multirow{2}{*}{ TNM } & \multicolumn{2}{|c|}{ Number of patients } \\
\cline { 3 - 4 } & $\mathrm{N}$ & $\%$ \\
\hline T1a & 7 & 20,0 \\
\hline T2a & 10 & 28,6 \\
\hline T2b & 7 & 20,0 \\
\hline T2c & 11 & 31,4 \\
\hline Total & 35 & $\mathbf{1 0 0 , 0 0}$ \\
\hline
\end{tabular}

Table 2. T status study group B

\section{Comparison of acute genitourinary toxicity - Acute GU}

Based on the results $\chi 2$ testa $(\chi 2=0,854 ; p=0,652)$ there was no statistically significant difference in the incidence of acute genitourinary toxicity between study group A and study group B despite escalated doses in group B (IMRT group). Registered acute genitourinary toxicity was Grade 1 and 2 (Chart 5). No one patient had acute genitourinary toxicity Grade 3.

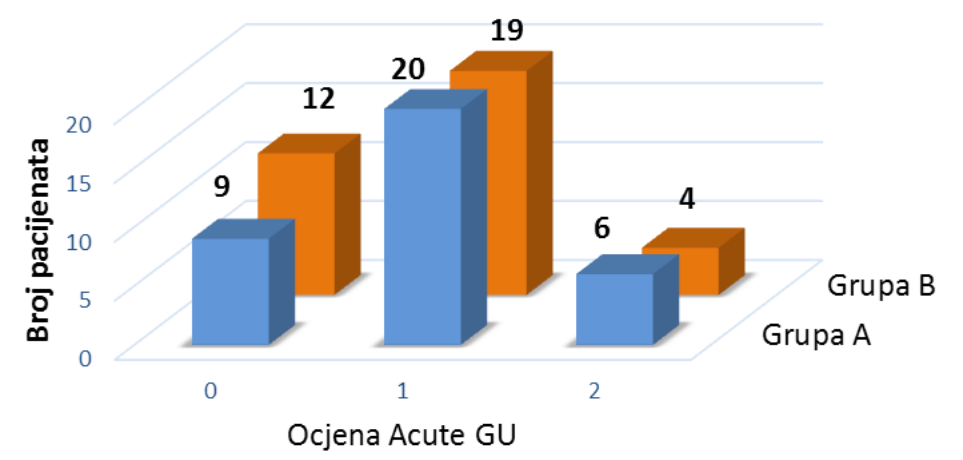

Chart 5. Distribution acute genitourinary toxicity GU study group A- blue and B-red

\section{Comparison of late genitourinary toxicity- Late GU}

Based on the results $\chi 2$ test $(\chi 2=1,936 ; p=0,380)$ there was no statistically significant difference in the incidence of late genitourinary toxicity between study group A and study group B despite escalated doses in group B (IMRT group) Chart 6. Registered late genitourinary toxicity was Grade 1 and 2. No one patient had late genitourinary toxicity Grade 3.

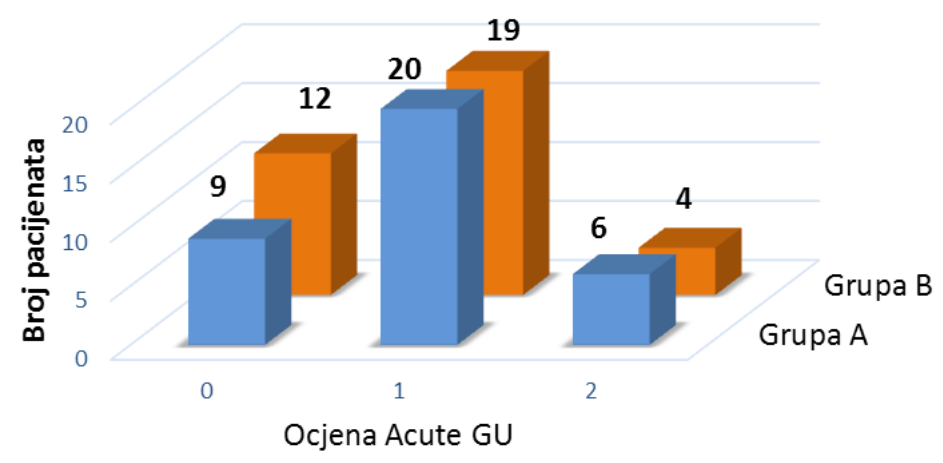

Chart 6. Distribution late genitourinary toxicity GU study group A and B 


\section{Comparison of acute gastrointestinal toxicity -Acute GI}

Based on the results Fisher exact testthere was no statistically significant difference $(p>0,05)$ in the incidence of acute gastrointestinal toxicity between study group A and study group B despite escalated doses in group B (IMRT group) Chart 7. Registered acute gastrointestinal toxicity was grades 1 and 2. No one patient had acute gastrointestinal toxicity Grade 3.

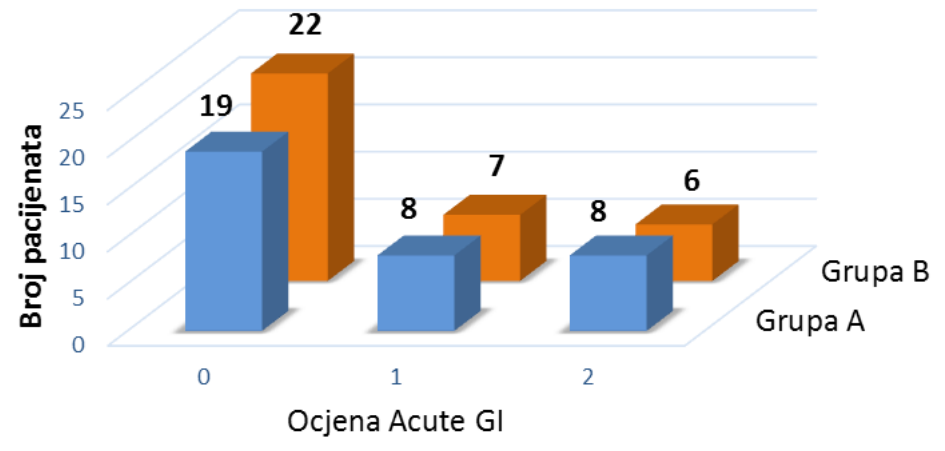

Chart 7. Distribution acute gastrointestonal toxicity-GI study group A and study group B

\section{Comparison of late gastrointestinal toxicity- Late GI}

Based on the results of Fischer exact test $(p=0,864)$ there were no statistically significant difference $(p>0$, 05 ) in the incidence of late gastrointestinal toxicity between study group A and study group B despite escalated doses in group B (IMRT group) Chart 8. Only one patient in the study group A, planned with ThreeDimensional Conformal RT, developed late gastrointestinal toxicity Grade 3. Other patients in study group A and $\mathrm{B}$ had registered late gastrointestinal toxicity Grade 1 and 2.

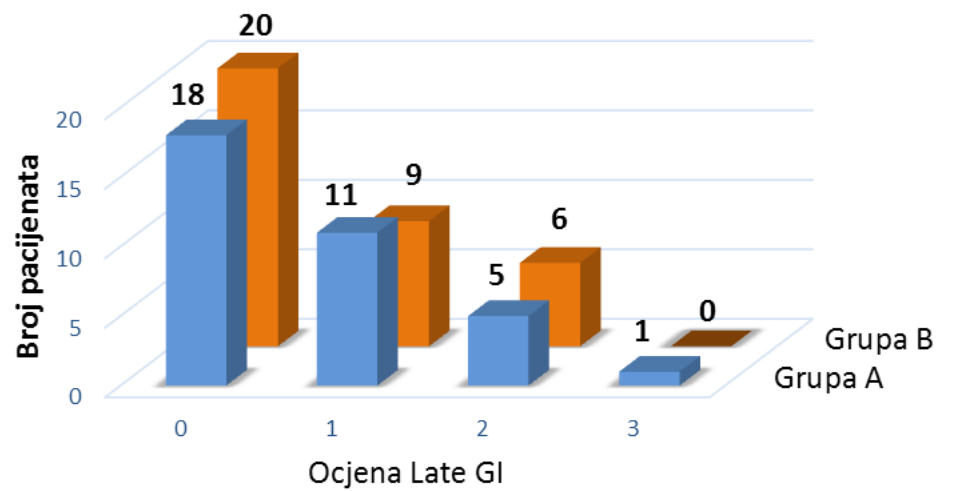

Chart 8. Distribution late Gastrointestinal toxicity-GI study group A and B

Radiation therapy has an extremely important role in the treatment of clinically localized prostate cancer. Radiation therapy may be indicated as monotherapy- the only modality of treatment in a group of low-risk patients and selected group of intermediate-risk patients. It can be indicated as concurrent with androgen deprivation radiotherapy in selected group of middle-risk and high-risk patients.Delivering a high radiation dose on the prostate with limitation of the dose to the surrounding organs of risk in terms of minimizing acute and late gastrointestinal and gastrointestinal effects is a significant challenge. As already mentioned, there are historical and prospective data that support the benefit of escalated radiation therapy dose in the treatment of clinically localized prostate cancer ${ }^{14}$. With 3D CRT technique it is possible to deliver radiation therapy dose up to $72-74$ Gy in maximum.

IMRT is promising technique which gives us possibility of escalation of radiation dose up to 78-80 Gy, and this technique today is preferable in every modern radiotherapy center. Two important randomized studies were published Pollack et al ${ }^{15}$, Zietman et al. ${ }^{16}$. 
These studies consistently demonstrate that higher radiation doses (78-79) Gy results in a reduction in recurrence of disease comparable to lower radiation doses. However, there is major concern that the delivery of high radiation doses can lead to an increased incidence of acute and late gastrointestinal and genitourinary toxicity.Using RTOG scale of toxic effects, only $1 \%$ of patients who received a lower conventional dose and $2 \%$ of patients who received a high dose had Gradus 3 toxicity ${ }^{16}$. There was no significant difference in grade 2 acute ( $42 \mathrm{vs} 49 \%$ ) or late ( $18 \%$ vs $20 \%)$ genitourinary toxicity, independent of the radiation dose that was delivered.

These results are in correlation with the results of the current study. Comparison in our study have shown that there was no statistically significant difference in acute and late genitourinary toxicity between study group A and study group B despite escalated doses in group B planned with IMRT technique. Acute genitourinary toxicity was Grade 1 and 2. No patient had acute genitourinary toxicity grade 3. The analysis of the results showed that there was no statistically significant difference between the study group A and B when the acute gastrointestinal toxicity were compared- Grade 1 and 2 . There was no acute gastrointestinal toxicity Grade 3. When it comes to late gastrointestinal toxicity, only one patient in the study group A planned with 3DCRT developed gastrointestinal toxicity grade 3 .

Other patients in study group $\mathrm{A}$ and $\mathrm{B}$ had late gastrointestinal toxicity Grade 1 and 2. These results are extremely important, because in the study group A patients were planned with 3DCRT technique and the total delivered dose was 70 Gy in 18 patients, and 74 Gy total dose was delivered in 17 patients of this group, while in the study group B the total dose delivered with IMRT technique was escalated to 78 Gy in all 35 patients.

Zelefsky et al reported that the 10-year follow-up of gastrointestinal morbidity was lower for patients treated with Intensity Modulated Radiotherapy 5\% compared with patients treated with Three-Dimensional Conformal Radiotherapy (13\%), despite the higher prescribed doses at the target volume in IMRT patients ${ }^{17}$.

Patients with clinically localized prostate cancer have a disease that is likely to be cured, so the issue of quality of radiation therapy treatment - (escalated radiation dose) and quality of life (gastrointestinal and genitourinary toxicity) after radical radiotherapy treatment is very important.

\section{Conclusion}

Compared with 3DCRT, IMRT is superior technique which permits escalation of radiation therapy dose without escalation of acute and late gastrointestinal and genitourinary toxicity. IMRT provide clinical benefitadequate local control because of escalated radiation dose, and acceptable incidence of acute and late toxicity.

\section{References}

1. Jemal A, Center MM, De Santis C, Ward EM. Global patterns of cancer incidence and mortality rates and trends. Cancer Epidemiol Biomarker Prev 2010;19(8):1893-907,

2. Schroder FH, Hugosson J, Roobol MJ, et al. Screening and prostate-cancer mortality in a randomized European study. N Engl J Med 2009; 360:1320-8,

3. NCCN Guidelines Version 1.2018. Prostate cancer.Januar 2018

4. Barry MJ, Albertsen PC, Bagshaw MA, et al. Outcomes for men with clinically nonmetastatic prostate carcinoma managed with radical prostatectomy, external beam radiotherapy,or expectant management: a retrospective analysis. Cancer 2001;91(12):2302-14,

5. Brundage M, Lukka H, Crook J, et al. The use of conformal radiotherapy ant the selection of radiation dose in $\mathrm{T} 1$ or T2 low or intermediate risk prostate cancer- a systematic review.RadiotherOncol 2002;64(3):12,

6. Al-Mamgani A, Heemsbergen WD, Peeters ST, Lebesque JV. Role of intensity-modulated radiotherapy in reducing toxicity in dose escalation for localized prostate cancer. Int J RadiatOncolBiolPhys 2009;73(3):685-691,

7. Kuban DA, Tucker SL, Dong L et al. Long-term results of the MD Anderson randomized dose-escalation trial for prostate cancer. Int J RadiatOncolBiolPhys 2008;70:67-74 
8. Peeters ST, Heemsbergen WD, Koper PC et al. Dose response in radiotherapy for localized prostate cancer: results of the Dutch multicenter randomized phase III trial comparing 68 Gy of radiotherapy with 78 Gy. J ClinOncol 2006;24:1990-1996

9. Zelefsky MJ, Fuks Z, Hunt M, et al. High-dose intensity modulated radiation therapy for prostate cancer: early toxicity and biochemical outcome in 772 patients. Int J RadiatOncolBiolPhys 2002; 53:1111-1116,

10. Rodriguez G, Ward P, Pickles T et al. Pre-treatment risk stratification of prostate cancer patients: A critical review. Can UrolAssoc J 2012; 6(2):121-127

11. Litzenburg D, Dawson AD, Sandler H, et al. Daily prostate targeting using implanted radiopaque markers. Int J RadiatOncolBiol Phys. 2002; 52(3):699-703,

12. Poggi MM, Gant DA, Sewchand W, Warlick WB. Marker seed migration in prostate localization.Int J RadiatOncolBiol Phys. 2003; 56(5):1248-51,

13. Cox JD etal.Toxicity criteria of Radiation Therapy Oncology Group (RTOG) and the European Organization for Research and Treatment of Cancer (EORTC). Int J RadiatOncolBiolPhys 1995; 31(5):1341-6.

14. Viani GA, Stefano EJ, Alfonso SL et al. Higher than conventional radiation doses in localized prostate treatment: A meta- analysis of randomized, controlled trials. Int J RadiatOncolBiolPhys 2009; 74(5):1405-18.

15. Pollack A, Zagars GK, Starkschall G, et al. Prostate cancer radiation dose response: Results of the M.D.Anderson phase III randomized trial. Int J RadiatOncolBiolPhys 2002; 53 (5):1097-1105

16. Zietman AL, De Silvio MR, Slater JD et al. Comparison of conventional dose vs high dose conformal radiation therapy in clinically localized adenocarcinoma of the prostate. JAMA 2005; 294: 1233-1239.

17. Zelefsky MJ, Levin EJ, Hunt M, et al. Incidence of late rectal and urinary toxicities after three dimensional conformal radiotherapy and intensity modulated radiation therapy for localized prostate cancer. Int J RadiatOncolBiolPhys 2008; 70( 4): 1124-1129.

Autor za korespondenciju:

Slavica Marić, Bul. Stepe Stepanovića 181b, Banja Luka+38766906773 - mail masa.maric3@gmail.com 